\title{
Pengaruh Jenis Larutan Perendaman Terhadap Sifat Fisik dan Organoleptik Keripik Kulit Ubi Kayu
}

\author{
Effect of Types of Soaking Solutions on Physical and Organoleptic Properties of Cassava Peel \\ Chips
}

\section{Gilian Tetelepta*, Agustina Souripet, Mary O. N. Somalay}

\author{
Jurusan Teknologi Hasil Pertanian, Fakultas Pertanian Universitas Pattimura \\ Jl. Ir. M. Putuhena Kampus Poka Ambon 97233 \\ *Penulis Korespondensi: E-mail: gilian_tetta@yahoo.com
}

\begin{abstract}
Cassava peel has high nutrient content and has the opportunity to be processed into chips. Processing of cassava peel chips requires soaking treatment to produce a crisper texture. The purpose of this study was determining the right type of soaking solution to produce the best cassava peel chips. The result showed that the immersion treatment with $\mathrm{CaCO}_{3}$ solution produced chips with the best physical properties having the hygroscopic value, absorption capacity, expansion volume of $0.105 \mathrm{~g}, 12.95 \%$, and 10,05\%, respectively. Organoleptically the chips were liked for its task (2.30), somewhat like for its colour (2.47) texture were liked (2.53) and overall the chips were liked (2.50) by panelist. The chips were also having a brown colour (3.03) and a crispy texture (3.13).
\end{abstract}

Keywords: cassava peel, chips, soaking solution

\begin{abstract}
ABSTRAK
Kulit ubi kayu memiliki kandungan gizi yang tinggi dan berpeluang untuk diolah menjadi keripik. Pengolahan keripik kulit ubi kayu memerlukan perlakuan perendaman agar menghasilkan tekstur yang lebih renyah. Tujuan penelitian ini untuk menentukan jenis larutan perendaman yang tepat untuk menghasilkan keripik kulit ubi kayu terbaik. Hasil penelitian menunjukkan bahwa perlakuan perendaman dengan larutan $\mathrm{CaCO}_{3}$ menghasilkan sifat fisik keripik terbaik dengan nilai higroskopis $0,105 \mathrm{~g}$, daya serap $12,95 \%$, volume pengembangan $10,05 \%$ dan berdasarkan uji hedonik menunjukkan rasa suka $(2,50)$, warna agak suka $(2,47)$, tekstur suka $(2,53)$ dan overall suka $(2,50)$ sedangkan untuk uji mutu hedonik menunjukkan warna coklat $(3,03)$ dan tekstur renyah $(3,13)$.
\end{abstract}

Kata kunci: keripik, kulit ubi kayu, larutan perendam

\section{PENDAHULUAN}

Ubi kayu (Manihot esculenta Crantz) merupakan salah satu sumber karbohidrat yang murah dan berpotensi untuk diekspor, sebagai bahan baku tapioka, industri fermentasi, dan berbagai industri makanan lainnya (Andrizal, 2003). Ubi kayu sudah lama dikenal oleh masyarakat sebagai bahan pangan yang sering dikonsumsi. Setelah umbinya diambil untuk di olah atau bahan baku industri lainnya, yang tersisa menjadi limbah yakni kulit ubi kayu.
Kulit ubi kayu memiliki kandungan gizi yang tinggi. Persentase kulit ubi kayu bagian dalam dapat mencapai $15 \%$ dari berat total ubi kayu (Permatasari et al., 2014). Menurut Kurniasih (2002), kulit ubi kayu biasanya dibuang begitu saja atau dijadikan sebagai pakan ternak. Kulit ubi kayu memiliki kandungan protein dan serat kasar lebih tinggi dibandingkan ubi kayu (Pratiwi, 2013). Kulit ubi kayu juga mengandung kadar asam sianida (HCN) sebesar 150-360 mg HCN per berat segar (Cuzin dan Labat, 1992). Kandungan HCN 
dalam kulit ubi kayu dapat dikurangi melalui beberapa perlakuan tertentu agar dapat dimanfaatkan dengan baik. Richana (2012) mengemukakan bahwa HCN mudah hilang ketika dilakukan proses perendaman, pengeringan, perebusan, fermentasi dan proses pengolahan lainnya. Kulit ubi kayu berpotensi untuk diolah menjadi produk makanan karena kadar gizi yang cukup tinggi. Karakteristik kulit ubi kayu yang tipis memungkinkan untuk diolah menjadi produk keripik yang renyah.

Keripik merupakan produk pangan yang diolah melalui proses penggorengan rendam dan memiliki kerenyahan sebagai karakteristik tekstur penting untuk dikontrol (Thanatuksorn et al., 2007). Hal yang mendorong terbentuknya kerenyahan keripik antara lain melalui perlakuan awal yang berupa perendaman menggunakan bahanbahan yang akan meningkatkan kekuatan gel pada proses gelatinisasi pati saat penggorengan keripik.

Beberapa senyawa yang dapat dipakai untuk merendam bahan dalam pembuatan keripik yaitu $\mathrm{CaCO}_{3}, \mathrm{CaCl}_{2}$ dan $\mathrm{NaCl}$. Hasil penelitian Putri (2012) bahwa penggunaan larutan $\mathrm{CaCO}_{3}$ dalam pembuatan keripik pisang kepok menghasilkan tekstur yang lebih baik. Sedangkan penggunaan larutan $\mathrm{CaCl}_{2}$ dalam pembuatan produk French fries dari kentang kualitas tenggo dan krespo menghasilkan tekstur agak renyah (Haryanti et al., 2013). Selain untuk mempertahankan kerenyahan, senyawa tersebut dapat menghilangkan asam oksalat dan juga HCN yang terdapat dalam bahan pembuatan keripik seperti pada kulit ubi kayu.

Tujuan penelitian ini adalah untuk menentukan jenis larutan perendaman yang tepat untuk menghasilkan keripik kulit ubi kayu terbaik

\section{METODE PENELITIAN}

\section{Bahan}

Bahan yang digunakan dalam penelitian ini adalah kulit ubi kayu, $\mathrm{NaCl}, \mathrm{CaCl}_{2}, \mathrm{CaCO}_{3}$, bawang putih, penyedap rasa (Royco) dan minyak kelapa (Bimoli). Semua bahan kimia yang digunakan adalah pure analysis.

\section{Pelaksanaan Penelitian}

\section{Pembuaan Keripik Kulit Ubi Kayu}

Pembuatan keripik kulit ubi kayu diawali dengan sortasi kulit ubi kayu. Kulit ubi kayu diambil secukupnya, serta dibersihkan, kemudian dikupas kulit ari yang berwarna coklat hingga tersisa kulit dalamnya saja yang berwarna putih kekuningan. Kulit ubi kayu tersebut dicuci sampai bersih kemudian dipotong berukuran $3 \times 3 \mathrm{~cm}$. Potongan ubi kayu tersebut kemudian direndam dalam larutan sesuai perlakuan yaitu air, $\mathrm{CaCl}_{2}$ $10 \%, \mathrm{CaCO}_{3} 10 \%$ dan $\mathrm{NaCl} 10 \%$ selama 20 menit. Setelah selesai perendaman, kulit ubi kayu dicuci sebanyak tiga kali menggunakan akuades dan ditiriskan. Setelah itu kulit ubi kayu direndam dalam bumbu dengan campuran air $25 \mathrm{~mL}$, bawang putih $25 \mathrm{~g}$ dan penyedap rasa (Royco) 2,5 g selama 1 jam. Kulit ubi kayu di keluarkan dan tiriskan airnya kemudian masukan dalam oven dan dikeringkan pada suhu $40^{\circ} \mathrm{C}$ selama 18 jam sampai kulit ubi kayu mengering. Kulit ubi kayu kering di goreng selama 5 detik, setelah itu didiamkan selama 5 menit untuk mengurangi kandungan minyak bahan. Keripik kulit ubi kayu kemudian dikemas dalam plastik polipropilen dan selanjutnya dianalisis sifat fisik dan organoleptik.

\section{Uji Fisik}

Parameter uji fisik yang diamati meliputi higroskopisitas (Wahyuningtyas et al., 2014), daya serap (Kusumaningrum, 2009), dan volume pengembangan (Setyaji et al., 2012).

\section{Uji Organoleptik}

Uji organoleptik menggunakan uji hedonik yang meliputi rasa, warna, tekstur dan overall. Uji mutu hedonik meliputi warna, dan tekstur.

\section{Analisis Data}

Data hasil penelitian dianalisis menggunakan analisis keragaman, bila terdapat perbedaan yang nyata atau sangat nyata maka pengujian beda rataan menggunaan uji beda nyata jujur (BNJ) pada taraf $95 \%$.

\section{HASIL DAN PEMBAHASAN}

\section{Higroskopis}

Higroskopis merupakan kemampuan produk dalam menyerap air. Nilai higroskopis berpengaruh pada lamanya produk melempem atau tidak dapat 
dikonsumsi lagi. Semakin besar nilai higros-kopis maka produk semakin cepat melempem, demikian juga sebaliknya (Murni et al., 2017). Pengujian higroskopis ini dilakukan selama 5 jam dan setiap jam ditimbang untuk mengetahui berat untuk masing-masing sampel dan kemudian dihitung berdasarkan selisih jam terakhir dengan jam ke-0.

Hasil analisis menunjukkan bahwa nilai higroskopis keripik kulit ubi kayu berkisar antara 0,015-0,105 g (Tabel 1). Nilai higroskopis tertinggi ditunjukkan oleh perlakuan jenis larutan $\mathrm{CaCO}_{3}$ yaitu sebesar $0,105 \mathrm{~g}$ dan berbeda nyata dengan perlakuan lainnya sedangkan nilai terendah terdapat pada perlakuan larutan perendaman air yaitu $0,015 \mathrm{~g}$. Tingginya nilai higroskopis pada perlakuan larutan perendaman $\mathrm{CaCO}_{3}$ dikarenakan $\mathrm{CaCO}_{3}$ ketika dilarutkan dalam air akan berdisosiasi menjadi $\mathrm{CaO}$ dan $\mathrm{CO}_{2}$. $\mathrm{CaO}$ yang terbentuk ini memiliki sifat higroskopis yang tinggi sehingga sangat mudah menyerap uap air dari udara. Hal inilah yang menyebabkan keripik yang direndam dalam larutan $\mathrm{CaCO}_{3}$ memiliki nilai higroskopis yang tinggi dibandingkan jenis larutan perendaman lain (Grandos et al., 2007). Hasil yang sama juga ditunjukkan oleh Wahyuningtyas et al. (2014), nilai higroskopis keripik pada perlakuan $\mathrm{CaCO}_{3}$ yang diperoleh lebih tinggi yaitu sebesar $0,076 \%$.

Keripik dengan pengembangan yang makin besar mempunyai kelemahan karena akan menyebabkan keripik bersifat mudah menyerap air (higroskopis) atau makin mudah melempem. Semakin tinggi kadar amilopektin dari bahan keripik maka kerenyahan keripik makin tinggi. Sebaliknya kerenyahan yang tinggi akan memudahkan keripik menyerap uap air di udara pada saat penyimpanan pada suhu ruang. Keripik menjadi berongga ketika digoreng karena air yang terdapat di dalam keripik keluar ke udara, sehingga pada saat penyimpanan pada waktu tertentu di suhu ruang, rongga-rongga udara yang menyebabkan kekerasan pada keripik akan menurun karena menyerap uap air. Semakin banyak air yang tidak teruapkan semakin mengurangi keporousan keripik sehingga kerenyahan menurun. Supartono (2000) menambahkan bahwa sifat produk keripik adalah kemudahan menyerap air (higroskopis), semakin mudah dan cepat menyerap air maka produk keripik akan semakin mudah melempem sehingga tidak renyah. Dengan demikian keripik kulit ubi kayu jadi lebih cepat melempem sehingga membutuhkan penanganan ekstra yakni yang direndam dengan larutan $\mathrm{CaCO}_{3}$.

\section{Daya Serap Keripik}

Daya serap keripik merupakan kemampuan keripik didalam menyerap minyak setelah digoreng. Daya serap yang tinggi menunjukkan terjadinya bagian yang matang dari keripik secara menyeluruh sehingga bagian tersebut menyerap banyak minyak. Jumlah minyak yang terkandung didalam permukaan keripik menyebabkan kondisi keripik menjadi sedikit lebih berat dan keripik menjadi matang. Hal ini tentunya berbeda jika keripik memiliki daya serap minyak yang kecil, selain memiliki bagian keripik yang tidak matang yang lebih besar, juga akan menyebabkan keripik berada dalam kondisi yang tidak mengembang (Kusumaningrum, 2009). Bahan pangan yang digoreng menyebabkan kandungan air dalam bahan menguap yang ditandai dengan timbulnya gelembung selama proses penggorengan. Bersamaan dengan itu bahan pangan menyerap minyak dengan persentase penyerapan tergantung pada jenis bahan yang digoreng (Lawson, 1985).

Berdasarkan hasil analisis, nilai daya serap keripik kulit ubi kayu berkisar antara 12,0712,95\%. Pada Tabel 1 terlihat bahwa antara semua jenis larutan perendaman tidak menunjukkan perbedaan yang nyata terhadap daya serap keripik antara perlakuan yang satu dengan yang lainnya.

Tabel 1. Pengaruh jenis larutan perendaman terhadap sifat fisik keripik kulit ubi kayu

\begin{tabular}{cccc}
\hline $\begin{array}{c}\text { Jenis Larutan } \\
\text { Perendaman }\end{array}$ & Higroskopis (g) & Daya Serap Keripik (\%) & Volume Pengembangan (\%) \\
\hline $\mathrm{Air}$ & $0,015 \mathrm{c}$ & 12,95 & $3,32 \mathrm{~b}$ \\
$\mathrm{CaCl}_{2}$ & $0,03 \mathrm{bc}$ & 12,37 & $7,12 \mathrm{a}$ \\
$\mathrm{CaCO}_{3}$ & $0,105 \mathrm{a}$ & 12,07 & $10,05 \mathrm{ab}$ \\
$\mathrm{NaCl}$ & $0,05 \mathrm{~b}$ & 12,09 & $78 \mathrm{a}$ \\
\hline
\end{tabular}

Keterangan: Notasi yang sama pada kolom yang sama menunjukkan tidak ada perbedaan yang nyata pada uji BNJ $(\alpha=$ $0,01)$ 
Dalam penelitian ini, semua bahan baku pembuatan keripik hanya direndam saja dengan jenis bahan perendam yang berbeda dalam jumlah volume tertentu. Dengan demikian tidak terjadi gelatinisasi karena tidak ada panas sehingga kulit ubi kayu tidak mengalami perubahan. Menurut Nurany et al. (2013), viskositas adonan juga dapat mempengaruhi tingkat penyerapan minyak goreng oleh bahan pada proses penggorengan. Semakin rendah viskositas adonan, maka akan semakin rendah tingkat penyerapan minyak goreng oleh bahan pada proses penggorengan. Tidak adanya perubahan pada kulit ubi kayu akibat proses gelatinisasi mengakibatkan tidak ada air yang terperangkap dalam bahan, selain air yang memang telah ada dari semula pada bahan. Hal ini menyebabkan ketika proses penggorengan, hanya sedikit air yang menguap dan jumlah air yang menguap itu digantikan dengan minyak yang terserap. Dengan demikian daya serap minyak untuk semua perlakuan larutan perendaman, tidak menunjukkan perbedaan yang nyata.

Menurut Zhang et al. (2016), pada awal proses penggorengan kadar air keripik sangat tinggi, keluarnya air menghalangi migrasi minyak ke bagian dalam keripik selama proses pencelupan. Semakin lama proses penggorengan keripik, semakin banyak terbentuk ruang kosong yang ditinggalkan oleh air yang menguap, air yang keluar menjadi lebih lemah sehingga lebih banyak minyak menembus bagian dalam produk keripik.

\section{Volume Pengembangan}

Volume pengembangan sangat penting untuk produk kerupuk akan tetapi untuk produk keripik sangat penting adalah kerenyahan. Dalam penggorengan, makin besar pemekaran keripik maka makin renyah, hal ini karena struktur amilopektin kurang kompak dan kurang kuat menahan pengembangan selama penggorengan. Selain itu juga yang penting dalam proses pengembangan adalah kandungan air. Saat penggorengan, air yang terdapat dalam keripik keluar ke udara dan menyisahkan rongga-rongga udara yang terbentuk karena pengembangan amilopektin. Pada pembuatan kerupuk, kandungan air bahan kerupuk besar karena telah melalui proses pengukusan yang akan mengakibatkan terbentuk gel pati yang mengandung air sehingga ketika digoreng, air itu dilepaskan ke udara dan rongga yang dibentuk mengembang. Akan tetapi untuk produk keripik, hanya melalui proses perendaman sehingga kandungan air bahan sedikit, yang menurunkan volume pengembangannya.

Kandungan air yang terikat pada gel pati merupakan hasil dari proses gelatinisasi. Gelatinisasi adalah peristiwa pembengkakan granula pati sedemikian rupa sehingga granula tersebut tidak dapat kembali kepada kondisi semula. Pada peristiwa ini molekul air akan masuk diantara bagian-bagian pati yang akan membentuk ikatanikatan gel pati. Untuk mendapatkan pengembangan volume keripik yang maksimum, kadar air yang terikat harus menyebar merata. Hal ini dapat dilakukan dengan menghomogenkan adonan sehingga proses gelatinisasi terjadi secara sempurna dan kandungan air tersebar secara merata (Koswara, 2009). Daya pengembangan produk di pengaruhi oleh adanya pati tergelatinisasi. Semakin banyak pati maka daya pengembangan lebih besar karena proses gelatinisasi granula-granula pati akan memberikan daya pengembangan lebih besar produknya daripada yang mengandung sedikit pati.

Berdasarkan Tabel 1 terlihat bahwa nilai volume pengembangan yang diperoleh berkisar antara $3,32-10,05 \%$. Nilai volume pengembangan tertinggi terdapat pada perlakuan larutan perendaman $\mathrm{CaCO}_{3}$ sebesar 10,05\% sedangkan nilai terendah terdapat pada perlakuan jenis larutan air yaitu 3,32\%. Perlakuan jenis larutan perendaman $\mathrm{CaCO}_{3}$ tidak berbeda nyata dengan larutan $\mathrm{NaCl}$ dan $\mathrm{CaCl}_{2}$ namun berbeda nyata dengan larutan perendaman air.

Tingginya volume pengembangan keripik pada perlakuan larutan perendaman $\mathrm{CaCO}_{3}$ disebabkan perlakuan perendaman dengan larutan kapur menyebabkan kulit ubi kayu mempunyai tekstur yang lebih baik dibandingkan dengan perendaman dalam larutan garam. Perubahan kekerasan kulit ubi kayu menjadi lunak ini dapat dicegah dengan perendaman dalam larutan kalsium (Ca) seperti larutan kapur. $\mathrm{Ca}(\mathrm{OH})_{2}$ adalah senyawa yang bersifat basa kuat dan biasanya digunakan sebagai larutan perendam pada beberapa jenis bahan makanan yang berfungsi untuk memberikan tekstur yang baik setelah bahan tersebut diproses dengan panas Wulandari (1999).

\section{Karakteristik Organoleptik Keripik Kulit Ubi Kayu}

\section{Rasa}

Penilaian panelis terhadap rasa keripik kulit ubi kayu seperti yang ditunjukkan pada Tabel 2 
berkisar antara 2,03-2,50 (agak suka-suka). Panelis memberikan penilaian tertinggi terhadap rasa pada keripik yang direndam dalam larutan $\mathrm{CaCO}_{3}$ yaitu 2,50 (agak suka) diikuti berturut-turut oleh larutan perendaman $\mathrm{CaCl}_{2}$ 2,46 (agak suka), air 2,3 (agak suka) dan $\mathrm{NaCl}$ 2,03 (agak suka).

Tingginya penilaian panelis terhadap rasa keripik kulit ubi kayu pada larutan $\mathrm{CaCO}_{3}$ diduga dipengaruhi oleh kerenyahan tekstur yang dihasilkan. Hasil ini sama dengan penelitian yang dilakukan oleh Lailatun et al. (2015), dimana rasa keripik yang direndam dengan larutan kapur mempunyai nilai yang lebih tinggi dibandingkan dengan larutan perendam air. Perendaman dalam air kapur dapat memberi tekstur yang lebih keras dan mengurangi rasa yang menyimpang, membuat tahan lama dan mencegah timbulnya warna atau pencoklatan.

\section{Warna}

Warna dalam bahan dapat berasal dari pigmen alami bahan pangan itu sendiri, reaksi karamelisasi, reaksi Maillard, reaksi senyawa organik dengan udara, dan penambahan zat warna baik alami maupun sintetik. Tabel 2 menunjukkan bahwa penilaian panelis untuk uji hedonik terhadap warna keripik kulit ubi kayu berkisar antara 2-2,73 (agak suka-suka), sedangkan untuk uji mutu hedonik berikisar dari 2,9-3,13 (coklat). Penilaian panelis tertinggi untuk uji hedonik warna terdapat pada larutan perendam $\mathrm{CaCl}_{2}$ 2,73 (suka), sedangkan nilai terendah terdapat pada bahan perendam $\mathrm{CaCO}_{3}$ 2,46 (suka), air 2,43 (agak suka) dan $\mathrm{NaCl} 2$ (agak suka). Namun berdasarkan uji mutu hedonik untuk ke empat jenis larutan perendamanan menunjukkan warna coklat. Perubahan warna keripik ubi kayu menjadi coklat tidak disebabkan oleh bahan perendam tetapi disebabkan oleh penggorengan dan reaksi millard (pencoklatan enzimatis). Minyak goreng sebagai penghantar panas menyebabkan keripik ubi kayu berubah menjadi kecoklatan (Nurainy et al., 2013).

Larutan perendam $\mathrm{CaCl}_{2}$ termasuk bahan pengeras sehingga mengurangi air dari keripik kulit ubi kayu dan menetralkan warna coklat yang sering muncul pada bahan sehingga panelis lebih memberikan panilaian tertinggi pada uji hedonik dan penilaian warna coklat untuk uji mutu hedonik (Fatah dan Bachtiar, 2004).

Bahan perendam $\mathrm{CaCO}_{3}$ berfungsi untuk memperbaiki tekstur dari suatu bahan tetapi tidak memberikan pengaruh terhadap warna bahan tersebut. Sedangkan perendaman dengan $\mathrm{NaCl}$ memberikan warna yang lebih putih, karena adanya aktifitas klorin yang memiliki sifat sebagai bahan pemutih. Garam natrium juga mampu mengikat kotoran, sehingga air rendaman Akan bebas kotoran dan menyebabkan bahan yang direndam memiliki tingkat kebersihan yang lebih tinggi (Mayasari, 2010).

\section{Tekstur}

Tabel 2 menunjukkan bahwa penilaian panelis untuk uji hedonik terhadap tekstur keripik kulit ubi kayu berkisar antara 2,23-2,53 (agak suka-suka), sedangkan untuk uji mutu hedonik berkisar antara 2,96-3,4 (renyah). Perbedaan tekstur pada keripik disebabkan oleh perbedaan perlakuan jenis larutan perendaman yang digunakan. Penilaian tekstur paling tinggi oleh panelis untuk uji hedonik yaitu bahan perendam $\mathrm{CaCO}_{3}$ dan $\mathrm{CaCl}_{2}$ dengan nilai yaitu 2,53 (suka), diikuti oleh bahan perendam air 2,46 (agak suka) dan $\mathrm{NaCl} 2,23$ (agak suka). Namun berdasarkan uji mutu hedonik tidak terdapat perbedaan dimana keempat jenis bahan perendam menunjukkan tekstur renyah.

Penelitian yang dilakukan oleh Yunus et al. (2017), menunjukkan bahwa keripik pepaya dengan perendaman kapur sirih dapat memperkuat kerangka bahan yang direndam. Penggunaan larutan perendaman $\mathrm{CaCO}_{3}$ dan $\mathrm{CaCl}_{2}$ lebih disukai panelis dan memiliki tekstur yang renyah, hal ini disebabkan karena ion kalsium pada $\mathrm{CaCO}_{3}$ dan $\mathrm{CaCl}_{2}$ akan berikatan dengan gugus karboksil dari pektin kulit ubi kayu membentuk Ca-pektin, sehingga akan mempertahankan tekstur keripik kulit ubi kayu sehingga tetap keras/renyah.

\section{Keseluruhan}

Hasil uji organoleptik terhadap overall keripik kulit ubi kayu rata-rata berkisar antara 2,13-2,56 yang secara deskriptif berkisar antara skala agak suka sampai suka. Tabel 2 menunjukkan bahwa perlakuan air menunjukkan tingkat kesukaan (overall) yang tertinggi terdapat pada perlakuan bahan perendam $\mathrm{CaCl}_{2}$ dan $\mathrm{CaCO}_{3}$. Hasil yang sama juga ditunjukkan oleh Lailatun et al. (2015) dimana tingkat overall penilaian panelis tertinggi terdapat pada bahan perendam $\mathrm{CaCl}_{2}$. 
Tabel 2. Pengaruh jenis larutan perendaman terhadap rasa, warna, tekstur, dan overall

\begin{tabular}{ccccccc}
\hline \multirow{2}{*}{$\begin{array}{c}\text { Jenis } \\
\text { Larutan } \\
\text { Perendaman }\end{array}$} & Rasa & \multicolumn{2}{c}{ Warna } & \multicolumn{2}{c}{ Tekstur } & Overall \\
\cline { 2 - 6 } & Hedonik & Hedonik & $\begin{array}{c}\text { Mutu } \\
\text { Hedonik }\end{array}$ & Hedonik & $\begin{array}{c}\text { Mutu } \\
\text { Hedonik }\end{array}$ & Hedonik \\
\hline Air & 2,30 & 2,43 & 3,03 & 2,46 & 3,26 & 2,47 \\
$\mathrm{CaCl}_{2}$ & 2,47 & 2,73 & 2,90 & 2,53 & 3,40 & 2,53 \\
$\mathrm{CaCO}_{3}$ & 2,50 & 2,47 & 3,03 & 2,53 & 3,13 & 2,50 \\
$\mathrm{NaCl}$ & 2,03 & 2,00 & 3,13 & 2,23 & 2,97 & 2,13 \\
\hline
\end{tabular}

\section{KESIMPULAN}

Berdasarkan hasil penelitian, maka dapat disimpulkan bahwa perlakuan larutan perendam $\mathrm{CaCO}_{3}$ menghasilkan karakteristik fisik dan organoleptik terbaik. Karakteristik fisik keripik kulit ubi kayu dengan perlakuan $\mathrm{CaCO}_{3}$ menghasilkan nilai higroskopis $0,105 \mathrm{~g}$, daya serap $12,07 \%$, volume pengembangan $10,05 \%$ dan berdasarkan uji organoleptik menunjukkan rasa, warna, tekstur dan overall yang disukai panelis.

\section{DAFTAR PUSTAKA}

Andrizal. 2003. Potensi, tantangan dan kendala pengembangan agroindustri ubi kayu dan kebijakan industri perdagangan yang diperlukan. Pemberdayaan Agribisnis ubi kayu mendukung ketahanan pangan. Balai Tanaman Kacang-kacangan dan Umbiumbian. Jakarta.

Fatah, M.A. dan Y. Bachtiar. 2004. Membuat Aneka Manisan Buah. Agro Media Pustaka. Jakarta.

Granados, M.L., M.D.Z. Poves, D.M. Alonzo, R. Mariscal, F.C. Galisteo, R. Moreno-Tost, J. Santamaria, and J.L.G. Fierro. 2007. Biodesel from Sunflower Oil Using Activated Calcium Oxide. Applied Catalysis B: $\quad$ Environmental 73: $317-326$. DOI: 10.1016/j.apcatb.2006.12.017

Haryanti, P., B. Sustriawan, dan Sujiman. 2013. Perendaman dalam kalsium klorida dan penggunaan edible coating untuk meningkatkan french fries dari kentang varietas tenggo dan krespo. Agritech 33: 3845.

Koswara, S. 2009. Teknologi Modifikasi Pati. Ebook Pangan.

Kurniasih, T.N. 2002. Pembuatan asam oksalat dari kulit ubi kay varietas randu dengan larutan $\mathrm{NaOH}$. Laporan Penelitian Universitas Muhammadiyah Surakarta. Surakarta.

Kusumaningrum, I. 2009. Analisa faktor daya kembang dan daya serap kerupuk rumput laut pada variasi proporsi rumput laut (Eucheuma cottonii). Jurnal Teknologi Pertanian 4: 63-68.

Lailatun, H., B. Admadi, dan I.G.A.L. Triani. 2015. Pengaruh Jenis bahan Perendam Terhadap Karakteristik Keripik Ketela Ungu (Ipomoea batatas). Jurnal Rekayasa dan Manajemen Agroindustri 3: 11-12.

Lawson, H.W. 1985. Standards for Fats and Oil. The AVI Publishing Compny, Inc. Weat Port, Connecticut.

Mayasari, S. 2010. Kajian karakteristik kimia dan sensoris sosis tempe kedelai hitam (Gycine soja) dan kacang merah (Pasheolus vulgaris) dengan bahan biji berkulit dan tanpa kulit. [Skripsi] Fakultas Pertanian UNS. Surakarta.

Murni, A., H. Rusmarilin, dan Ridwansyah. 2017. Pendugaan umur simpan kerupuk bawang kentang dengan metode akselerasi berdasarkan pendekatan kadar air kritis. Jurnal Rekayasa Pangan dan Pertanian 5: 11-25.

Nurainy, F., O. Nawansih, dan D. Haryanto. 2013. Penyusunan Draft Standar Operating Procedur (SOP) Pengolahan Keripik Pisang (Studi Kasus Di Salah Satu Industri Rumah Tangga Keripik Pisang Bandar Lampung). Fakultas Pertanian, Universitas Lampung.

Permatasari, A.R., L.U. Khasanah, dan E. Widowati. 2014. Karakterisasi karbon aktif kulit singkong (Manihot utilisima) dengan variasi jenis aktivator. Jurnal Teknologi Hasil Pertanian 7: 70-75.

Pratiwi, I.D. 2013. Pengaruh substitusi tepung kulit singkong terhadap kualitas muffin. [Skripsi] 
Jurusan Teknologi Jasa dan Produksi Fakultas Teknik Universitas Negeri Semarang.

Putri, A.R. 2012. Pengaruh kadar air terhadap tekstur dan warna keripik pisang kepok (Musa parasidiaca formatypica). [Skripsi] Jurusan Teknologi Pertanian Fakultas Pertanian Universitas Hasanuddin, Makassar.

Richana, N. 2012. Ubi Kayu dan Ubi Jalar. Nuansa. Bandung.

Setyaji, H., V. Suwita, dan A. Rahimsyah. 2012. Sifat kimia dan fisika kerupuk opak dengan penambahan daging ikan gabus (Ophiocephalus striatis). Jurnal Penelitian Universitas Jambi 14: 17-22.

Supartono, W. 2000. Pengembangan dan Standarisasi Kualitas Kerupuk Rambak. Seminar Nasional Industri Pangan. Fakultas Teknologi Pertanian, Universitas Gadjah Mada. Yogyakarta.

Thanatuksorn, P., K. Kajiwara, and T. Suzuki. 2007. Characterization of deep-fat frying in a wheat flour-water mixture model using a state diagram. Journal Science Food Agriculture 87: 2648-2656. DOI: 10.1002/jsfa.3027

Wahyuningtyas, N., Basito, dan W. Atmaka. 2014. Kajian karakteristik fisikokimia dan sensoris kerupuk berbahan baku tepung terigu, tepung tapioka dan tepung pisang kepok kuning. Jurnal Teknosains Pangan 3: 76-85.

Wulandari. 1999. Pengaruh Konsentrasi $\mathrm{Ca}(\mathrm{OH})_{2}$ Sebagai Larutan Perendaman dan Lama Perendaman Terhadap Kualitas Manisan Kulit Melinjo Kering. [Skripsi] THP FTP, Universtias Brawijaya. Malang.

Yunus, R., H. Syam, dan P. Jamaluddin. 2017. Pengaruh persentase dan lama perendaman dalam larutan kapur sirih $\mathrm{Ca}(\mathrm{OH})$ terhadap kualitas keripik pepaya (Carica papaya L.) dengan vacuum frying. Jurnal Pendidikan Teknologi Pertanian 3: 221-233.

Zhang, T., J. Li., Z. Ding, and L. Fan. 2016. Effects of initial moisture content on the oil absorption behavior of potato chips during frying process. Food Bioprocess Technology 9: 331-340. 